\title{
Survey of Physical, Chemical, and Microbial Water Quality in Greenhouse and Nursery Irrigation Water
}

\author{
Dustin P. Meador ${ }^{1}$, Paul R. Fisher ${ }^{1,5}$, Philip F. Harmon ${ }^{2}$, \\ Natalia A. Peres ${ }^{3}$, Max Teplitski ${ }^{4}$, and Charles L. Guy ${ }^{1}$
}

AdDitional INDEX wORDs. aerobic bacteria, chemical oxygen demand, chlorine, clogging, sanitation, suspended solids, water treatment

Summary. The objective was to analyze the physical, chemical, and biological water quality in horticulture irrigation systems in 24 ornamental plant greenhouses and nurseries in the United States. At each greenhouse or nursery, water was collected from up to five points ("Sample Types") which included 1) "Source" from municipal or private well supplies, 2) "Tank" from enclosed storage containers, 3) "Subirrigation" from water applied to crops in ebb-and-flood systems, 4) "Furthest Outlet" that were irrigation emitters most distant from the Source, and 5)

"Catchment Basin" from open outdoor retention areas. On average, Source water had the highest physical and microbial quality of Sample Types including the highest ultraviolet (UV) light transmission at $86 \%$, lowest total suspended solids (TSS) at $3.1 \mathrm{mg} \cdot \mathrm{L}^{-1}$, and lowest density of aerobic bacteria with $1108 \mathrm{cfu} / \mathrm{mL}$ of water. Average quality of recycled water from Subirrigation or Catchment Basins did not meet recommended levels for horticultural irrigation water for UV transmission (68\% to $72 \%$ compared with recommended $75 \%)$, microbial counts $(>100,000 \mathrm{cfu} / \mathrm{mL}$ compared with recommended $<10,000 \mathrm{cfu} / \mathrm{mL})$, and chemical oxygen demand (COD) (48.2 to $61.3 \mathrm{mg} \cdot \mathrm{L}^{-1}$ compared with recommended $\left.<30 \mathrm{mg} \cdot \mathrm{L}^{-1}\right)$. Irrigation water stored in Tanks or applied at Furthest Outlets had lower physical and biological water quality compared with Source water. Level of aerobic bacteria counts highlighted a risk of clogged microirrigation emitters from microbial contaminants, with highest bacteria levels in recirculated irrigation water. The physical, chemical, and microbial water quality results indicate a need for more effective water treatment to improve biological water quality, particularly with recirculated irrigation.

$\mathrm{H}$ orticultural operations are increasingly using recirculating subirrigation systems and runoff water collected in catchment basins to supplement decreasingly available potable water sources for irrigation (Obreza et al., 2010). Irrigation water that is collected for use in catchment basins (capture-andreuse) or recirculating (ebb and flood) irrigation systems are characterized by

We thank the USDA-ARS Floriculture and Nursery Research Initiative, and industry partners of the Floriculture Research Alliance at the University of Florida (floriculturealliance.org) and Water Education Alliance for Horticulture (watereducationalliance.org) for supporting this research.

${ }^{1}$ Environmental Horticulture Department, University of Florida, IFAS, 1533 Fifield Hall, Gainesville, FL 32611

${ }^{2}$ Plant Pathology Department, University of Florida, IFAS, 1453 Fifield Hall, Gainesville, FL 32611

${ }^{3}$ Plant Pathology Department, University of Florida, IFAS, GREC, 14625 County Road, Wimauma, FL 33598

${ }^{4}$ Soil and Water Sciences, University of Florida, IFAS, 1376 Mowry Road, Gainesville, FL 32611

${ }^{5}$ Corresponding author. E-mail: pfisher@ufl.edu. elevated levels of physical, chemical, and biological contaminants that result in lower water quality, compared with potable water (Gilbert et al., 1980; Runia , 1994). When irrigating with low quality water, the combined physical, chemical, and microbial variables can result in microirrigation emitter and filter clogging and promote biofilm formation on critical surfaces within the water distribution systems (Bucks et al., 1979; Ravina et al., 1997). A report by Hong and Moorman
(2005) compiled research that identified 16 species of Phytophthora (including the plant pathogen Phytophthora ramorum), 26 species of Pythium, 10 viruses, waterborne plant pathogens, and other microorganisms in irrigation water samples collected from nursery and greenhouse operations.

Sanitation technologies are incorporated into horticulture irrigation systems to provide control of pathogens, improve plant health and prevent the development of secondary inoculum or protective overwintering structures (Agrios, 1997). These technologies include filtration, chlorination, copper ionization, ozonation, UV light, use of activated peroxygens, chlorine dioxide, heat, or other technologies to provide disinfestation of irrigation water (van Os, 2009). Water quality variables such as suspended particles, dissolved organic and inorganic molecules, and microbes create a demand on sanitizing agent active ingredients, thereby reducing the efficacy of water treatment technologies for control of microbes, pathogens, and algae (Copes et al., 2004; Ravina et al., 1997; Sutton et al., 2006).

Monitoring of biological, physi$\mathrm{cal}$, and chemical variables is necessary to ensure water quality is adequate for its intended use. For example, a standard evaluation for health and operational safety at food and beverage processing and recreational swimming facilities monitors biological variables such as counts of aerobic bacteria and fungi to indicate contamination or ineffective treatment [American Public Health Association (APHA), 1995; Maier et al., 2009]. The reduction of bacterial counts from water samples collected before vs. after water treatment is used as a measure of effective control by a sanitizing agent, according to the U.S. Environmental Protection Agency (USEPA, 1999). Physical

\begin{tabular}{llll}
\hline $\begin{array}{l}\text { Units } \\
\begin{array}{l}\text { To convert U.S. to SI, } \\
\text { multiply by }\end{array}\end{array}$ & U.S. unit & SI unit & $\begin{array}{l}\text { To convert SI to U.S., } \\
\text { multiply by }\end{array}$ \\
\hline 29.5735 & $\mathrm{fl} \mathrm{oz}$ & $\mathrm{mL}$ & 0.0338 \\
0.3048 & $\mathrm{ft}$ & $\mathrm{m}$ & 3.2808 \\
0.0929 & $\mathrm{ft}^{2}$ & $\mathrm{~m}^{2}$ & 10.7639 \\
3.7854 & $\mathrm{gal}$ & $\mathrm{L}$ & 0.2642 \\
2.54 & inch(es) & $\mathrm{cm}$ & 0.3937 \\
1 & micron & $\mu \mathrm{m}$ & 1 \\
1000 & $\mathrm{mmho} / \mathrm{cm}$ & $\mu \mathrm{SS} \cdot \mathrm{cm}^{-1}$ & 0.0010 \\
1 & $\mathrm{ppm}$ & $\mathrm{mg} \cdot \mathrm{L}^{-1}$ & 1 \\
6.8948 & $\mathrm{psi}$ & $\mathrm{kPa}$ & 0.1450 \\
$\left({ }^{\circ} \mathrm{F}-32\right) \div 1.8$ & ${ }^{\circ} \mathrm{F}$ & ${ }^{\circ} \mathrm{C}$ & $\left({ }^{\circ} \mathrm{C} \times 1.8\right)+32$
\end{tabular}


contaminants from plant debris, peatmoss, sand, and insoluble salts can restrict water flow, create a sanitizing agent demand, reduce UV transmission, and shield target pathogens from contact with a sanitizer (Copes et al., 2004; Gauthier et al., 1999; Pettygrove and Asano, 1985; Pirovanni et al., 2004; Rogers et al., 2003). Chemical aspects of water quality, including $\mathrm{pH}$, total dissolved solids, alkalinity, and nitrogen, can decrease the efficacy of sanitizing treatment to provide pathogen and pest control. High solution $\mathrm{pH}$ and reduced forms of nitrogen in organic and inorganic compounds, such as ammonium in water-soluble fertilizers, can reduce the availability of strong oxidizers such as hypochlorous acid (APHA, 1995; Feben and Taras, 1955; Heibling and VanBriessen, 2008; Tanwar et al., 2008).

Surveys have been conducted to assess chemical water quality (Argo et al., 1997) and pathogen presence in ornamental greenhouses and nurseries (Hong and Moorman, 2005). Water quality information is lacking on whether levels of water contaminants such as suspended solids, aerobic bacterial density, and COD meet recommended guidelines. If physical, chemical, and microbial load are outside of recommended guidelines, there is increased risk that treatment technologies will not provide effective control of target pathogens, algae, and biofilm in recirculated irrigation systems.

The objective of this study was to quantify physical, chemical, and microbial load and overall sanitizing demand at key sampling points within irrigation systems, using a field survey approach at multiple greenhouse and nursery locations. These values were compared against published irrigation guidelines for effective sanitation treatment for control of pathogens, algae, and biofilm, and for adequate nutrient management of horticultural crops.

\section{Materials and methods}

Field surveys were conducted at 24 greenhouse and nursery ("Locations") across 11 states in the United States, during a period of active crop production from April to July 2009. Surveyed Locations had an average production area of $985,546 \mathrm{ft}^{2}$ (Table 1 ), ranging from 72,000 to $6,533,989 \mathrm{ft}^{2}$. The reported average daily water use among the Locations was $160,724 \mathrm{gal}$ with a range of 6001 to $1,000,105 \mathrm{gal}$. Overall, an average of $33 \%$ or 43,605 gal (range from $0 \%$ to $100 \%$, or 0 to $1,000,105 \mathrm{gal})$ was from recycled water, defined as Subirrigation (recirculated ebb-and-flood) or Catchment Basin (a combination of rainwater, runoff, and other sources). The sampled population of greenhouse and nursery Locations produced a variety of seedling plug and cutting transplants and finished containerized ornamental crops. Growers who managed recycled or treated irrigation, and who had participated in previous water quality extension workshops by the authors in several U.S. states, were selected to participate if they were willing to comply with a standardized sample collection and handling protocol.

Water samples were collected at points within each Location that represented up to five Sample Types: Source, Tank, Subirrigation, Furthest Outlet, and Catchment Basin. Source represented municipal supply or well water that was collected from an inline main (6-10 inches) pipe or pressurized expansion tank at the first access point in each nursery (most upstream access point within each of the Locations). Tank water was collected from enclosed containments of treated (chemical sanitizer, filtration, or both) irrigation solution before going through distribution plumbing. Furthest Outlet was the irrigation solution at the point of application to the crop located furthest away from the Source, after passing through the distribution plumbing, and was collected from overhead, drip, or hand-held nozzles. Subirrigation samples were collected from recycled ebb-and-flood irrigation during a flood cycle and before filtration or sanitizer treatment. Catchment Basin samples were collected from an outdoor, open surface area that received runoff and recycled irrigation water and from the depth of the pump intake valve, before filtration or treatment.

To determine the effect of water treatment on microbial density in irrigation water during crop production, counts were made on additional samples collected from Locations that treated water with sanitizer injection or membrane filtration (Table 1). Eight Locations provided water treatment to recycled irrigation, nine Locations treated well or municipal Source water, and seven Locations did not use sanitizers or membrane filtration. Samples collected at the closest sampling points before and after sanitizer or membrane filtration were identified as pretreatment and posttreatment. Pretreatment samples from Source water had not received any sanitizer or membrane filtration after water entered the greenhouse, whereas pretreatment samples from Subirrigation and Catchment Basins were collected after an irrigation event, before additional filtration or sanitizer treatment. Recycled water was reported as the percentage of daily water used at each Location that was collected and used again for irrigation.

The experimental design was a split plot with Location as the main plot and Sample Type as the subplot. Effects were analyzed using analysis of variance using GLM (SAS version 9.1; SAS Institute, Cary, NC) including Location (24 levels), Sample Type (5 levels), and Sample Type $\times$ Location interaction, where the sampling time during the day within each Location was a random variable used as the error term. Because of differences in irrigation system design, not all of the 24 Locations had all five Sample Types. Additional analysis of pretreatment and posttreatment was conducted using MIXED (SAS version 9.1).

Techniques for collection, handling, and laboratory processing followed standard methods (APHA, 1995). Three replicates of 350-mL samples were collected in Whirl-Pak ${ }^{\mathrm{TM}}$ (Nasco, Modesto, CA) sterile collection bags from the five Sample Types. A total of 15 samples were collected at each of the Locations, by a trained grower or supervised employee during $1 \mathrm{~d}$ of production. Each Location was sampled once during the 6 weeks of collection and analysis. Four Locations per week shipped their samples overnight to the University of Florida in insulated coolers with ice packs and digital data loggers (HOBO; Onset Computers, Bourne, MA) to ensure environmental stability and sample integrity during collection and shipment. All samples were received for processing and analysis within $20 \mathrm{~h}$ from the time they were collected and were maintained between 22 to $25^{\circ} \mathrm{C}$.

Physical water quality was determined by TSS, as described in Current Method 2540 D (APHA, 1995). A vacuum pump (model 4144; Emerson, St. Louis, MO) applied a constant 


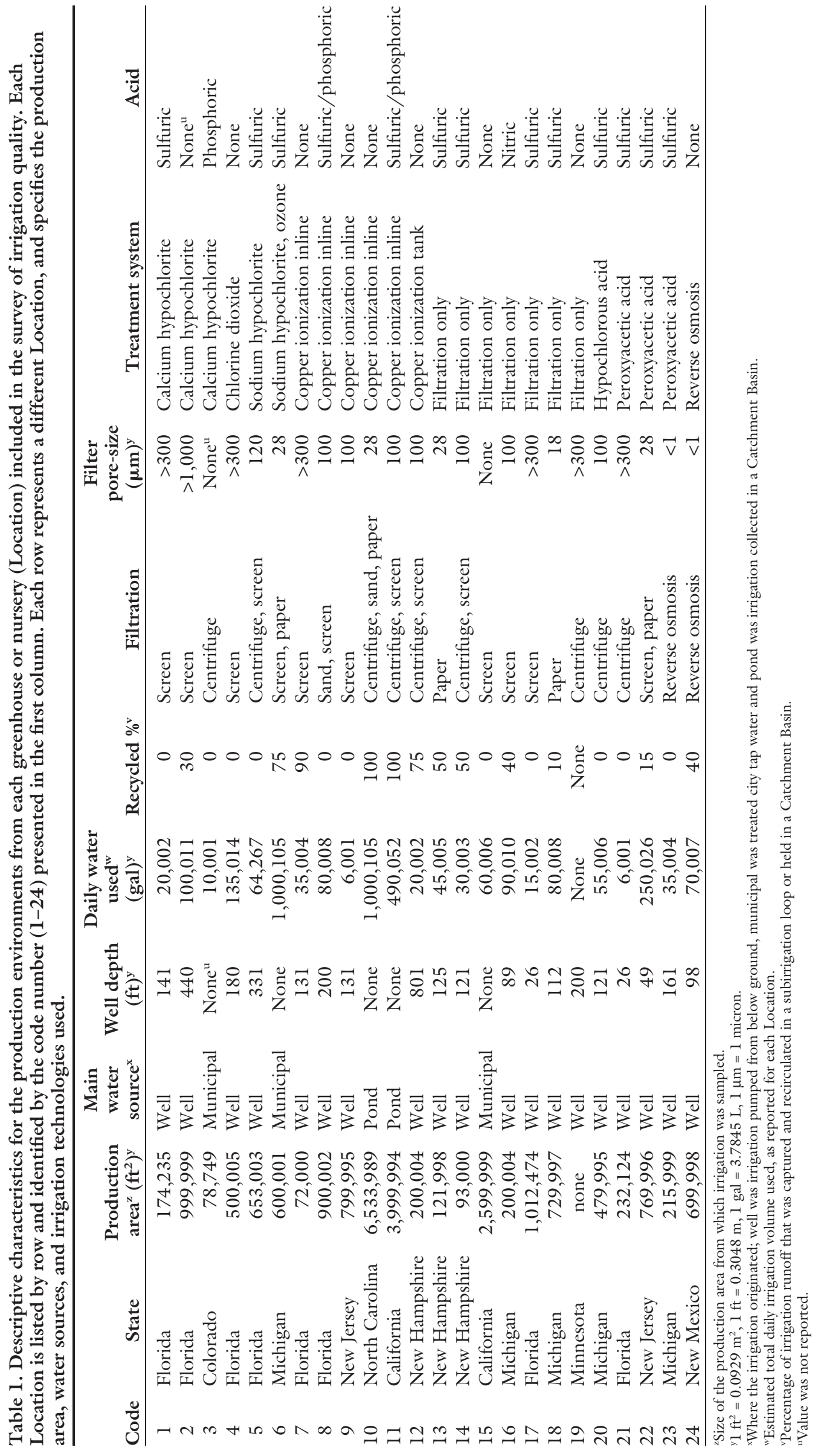


suction of $200 \mathrm{kPa}$ to filter each $200 \mathrm{~mL}$ sample through a $4.25 \mathrm{~cm}$ preweighed $\mathrm{GF} / \mathrm{C} \quad 0.45 \mu \mathrm{m}$ glass fiber filter (Whatman-GE, Maidstone, UK) to recover all suspended particles (particles smaller than $0.45 \mu \mathrm{m}$ were assumed to be dissolved solids). Organic carbon was analyzed using the loss on ignition procedure where weighed filters from previous TSS analysis were ignited in a muffle furnace at $550{ }^{\circ} \mathrm{C}$ to volatilize the organics and then reweighed according to standard methods (APHA, 1995). The UV transmission was determined by spectrophotometry at $254 \mathrm{~nm}$, as described by Chang et al. (1998) using a spectrophotometer (SpectraMax Plus model 384; Molecular Devices, Sunnyvale, CA) and an analytical software package (SoftMax-Pro, Molecular Devices).

Chemical water quality was evaluated using several testing methods outlined by the USEPA (2004). The COD was determined by colorimetric analysis using a digital colorimeter (ORION 4000; Thermo-Fisher, Barrington, IL) and COD AQUAfast IV test ampoules containing potassiumdichromate and mercuric sulfate (Thermo-Fisher). Digestion with a COD block incubator (Hach, Loveland, CO) was followed by analysis using the closed reflux colorimetric method 5220 B (APHA, 1995). Chemical measurements of $\mathrm{pH}$, alkalinity, dissolved oxygen and electrical conductivity (EC) were conducted using methods described by the Association of Agricultural Chemists (AOAC), 1999. Chlorine demand was evaluated at 2 min using standard method 4500-Cl G (APHA, 1995).

Microbial analysis was performed using a dry rehydratable culture substrate, direct count plates (Petrifilm ${ }^{\mathrm{TM}}$; 3M Microbiology, St. Paul, MN) formulated for aerobic bacteria cultures or yeast and molds. Each culture contained a dehydrated substrate mounted on a flexible card where microbial colonies are detected and counted with the aid of a color indicator to enumerate living microbial densities. Irrigation samples were transferred into culture immediately after samples were removed from insulated shipping coolers and allowed to reach to room temperature. Microbiological methods followed official methods: 990.12, Petrifilm Aerobic Count Plates and 997.02, Yeast and Mold Count Plate (AOAC, 1999). Serial dilutions were carried out at 1 to $10^{8}$ dilutions for aerobic bacteria and one to $10^{4}$ for yeasts and molds, and sterilized water was used as control. Each serial dilution was cultured on aerobic bacteria as well as yeast and mold substrate with three replicates each. Cultures were incubated at $74^{\circ} \mathrm{F}$ in the dark for 3 to $7 \mathrm{~d}$, until counts were stable. Magnification $(\times 10)$ was used to obtain colony counts for each culture. Counts were made from the selected dilution, which resulted in 10 to 250 $\mathrm{cfu} / \mathrm{mL}$ on the aerobic count plates and from 10 to $150 \mathrm{cfu} / \mathrm{mL}$ on yeast and mold count plates.

\section{Results and discussion}

Physical water quality variables had significant main effects for Sample Type and Location with TSS and UV transmission variables, and main and interaction effects for organic carbon. Clogging risk was evaluated using the Bucks et al. (1979) clogging index for microirrigation systems, whereby levels of physical, chemical, and biological contaminants were each rated a value from 0 (no risk) to 10 (severe risk); a combined total of 10 or less represented low clogging risk; a combined total of 20 or more would represent a severe risk and indicate need for treatment. TSS level was insufficient to indicate a physical clogging risk according to the Bucks et al. (1979) scale (Table 2). A TSS below $5 \mathrm{mg} \cdot \mathrm{L}^{-1}$ is recommended when reuse water will be treated with a chemical oxidizer (USEPA, 1999), and this recommended level was exceeded for Furthest Outlet, Subirrigation, and Catchment Basin samples. Water used to irrigate food crops in Florida has a TSS limit of $5 \mathrm{mg} \cdot \mathrm{L}^{-1}$, with a limit of $20 \mathrm{mg} \cdot \mathrm{L}^{-1}$ for nonfood crops (USEPA, 2004) that would apply to the ornamental crops grown in survey Locations.

The average physical water quality for Sample Types other than the Source did not meet published guidelines for irrigation use in terms of organic carbon and UV transmission (Table 2). The guideline for effective disinfestation with UV treatment is a UV transmission of at least $75 \%$ at the 254-nm wavelength (Newman, 2004). Lower water quality is indicated if total organic carbon is above $2 \mathrm{mg} \cdot \mathrm{L}^{-1}$ because UV transmission and efficacy of sanitizing agents both decrease (Chang et al., 1998; USEPA,
1999). Samples collected from the Source had the highest physical quality among the Sample Types in terms of higher UV transmission and lower levels of TSS and organic carbon compared with Subirrigation and Catchment Basin samples. Although TSS in Source water samples was below $10 \mathrm{mg} \cdot \mathrm{L}^{-1}$ in all Locations, six Locations had organic carbon levels above the recommended $2 \mathrm{mg} \cdot \mathrm{L}^{-1}$ (between 2.1 and $7.1 \mathrm{mg} \cdot \mathrm{L}^{-1}$ ). Only one Location had low physical quality from the Source indicated by a low UV transmission that was below the recommended $75 \%$. At all of the other Locations the higher UV transmission (above 75\%) indicated suitability of sanitation with UV treatment. Physical water quality variables did not differ $(P>0.05)$ between Subirrigation and Catchment Basins or between Tank and Furthest Outlet. After the Source, the decreased UV transmission may have resulted from a combination of TSS and dissolved micronutrient chelates and fertilizer dyes. Organic carbon comprised between $51 \%$ and $69 \%$ of TSS, depending on the Sample Type, with the remaining $31 \%$ to $49 \%$ consisting of nonignitable mineral particulates. Because the organic carbon component of TSS can be oxidized, samples with a high proportion of organic carbon would be likely to increase sanitizing agent demand.

There was a moderate risk of clogged drip emitters from chemical contaminants according to the Bucks et al. (1979) scale. However, alkalinity, total dissolved solids, and EC of Source water were within the water quality recommendations for use on floriculture crops. Chemical water quality variables had significant main effects for Location for all chemical water quality measurements. Sample Type affected chemical water quality variables other than alkalinity (Table 2 ). Management of $\mathrm{pH}$ is important both for nutrient management and its effects on activity of sanitizers such as chlorine (decreasing the availability of the strong sanitizing form of hypochlorous acid with increased $\mathrm{pH}$ ) and copper (decreased solubility with increasing $\mathrm{pH})$. Average $\mathrm{pH}$ was outside the recommended guidelines for Source and Catchment Basin. Appropriate treatment to decrease alkalinity and $\mathrm{pH}$ would include acid injection and possibly reverse osmosis. Total 


\section{Research Reports}

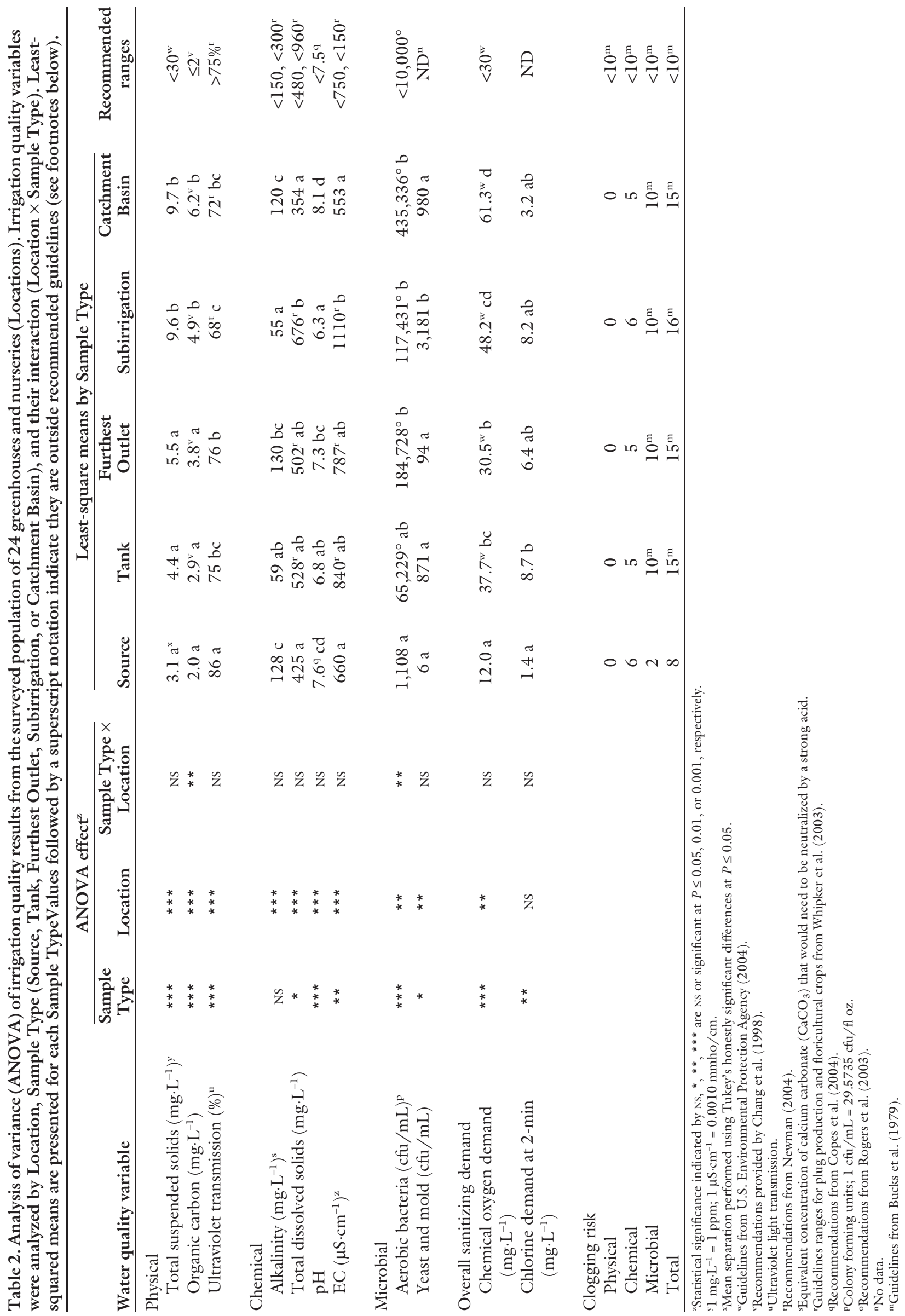


Table 3. Analysis of variance table for aerobic bacteria and yeast and mold densities for each greenhouse and nursery (Location) surveyed. At each Location, samples were collected at the Source and Furthest Outlet. For Location 7, there were two Source and Furthest Outlet irrigation circuits, which were analyzed separately. Locations 20 and 24 did not have Furthest Outlet sampling points and were not included. The reported densities of aerobic bacteria and yeast and mold are least-square means for each Location, with statistical comparison between Source and Furthest Outlet by Location.

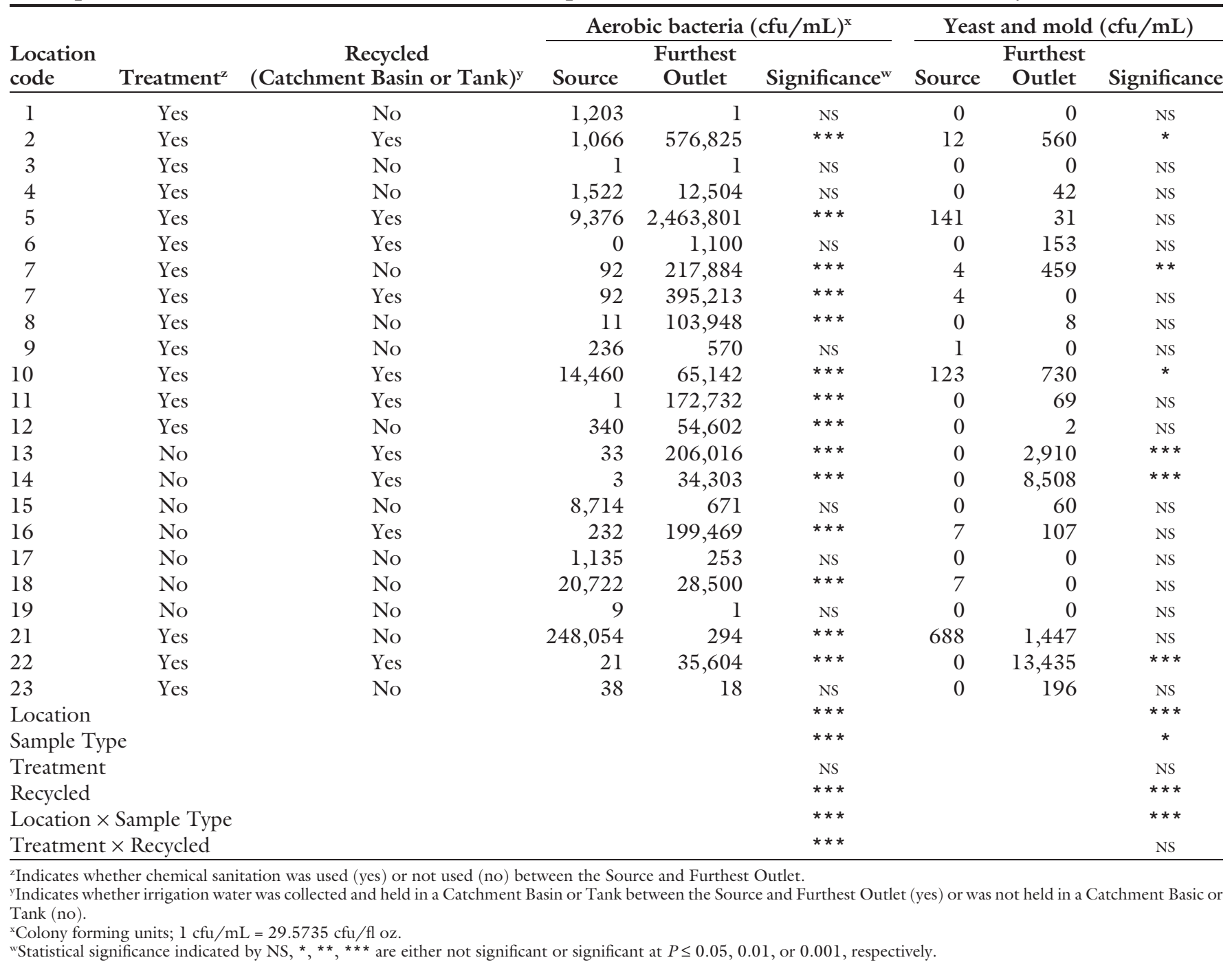

dissolved solids were measured with an EC meter, in contrast with filtered TSS, which represented particles larger than $0.45 \mu \mathrm{m}$ in diameter. Total dissolved solids and alkalinity can result in precipitation of inorganic components and combined compounds such as calcium carbonate. Total dissolved solids and EC for Source water were within recommended values for production ornamental crops (Whipker et al., 2003). Higher total dissolved solid and EC values in Tank, Furthest Outlet, and Subirrigation may not indicate a problem because these Sample Types included water-soluble fertilizer that was injected immediately after the Source. According to criteria from Bucks et al. (1979), the Source and Subirrigation had a $6 / 10$ chemical risk of emitter clogging and a rating of 5 for other Sample Types.

Source samples had the lowest aerobic bacteria counts of all Sample Types, and Subirrigation samples had the highest yeast and mold counts. There were significant main effects for Sample Type and Location for aerobic bacteria as well as yeast and mold, with a significant interaction for aerobic bacteria. Microbial water quality variables for Source water were within the recommended guidelines, whereas Tanks, Furthest Outlet, Subirrigation, and Catchment Basin had aerobic bacteria above the recommended $10,000 \mathrm{cfu} / \mathrm{mL}$ (Table 2). There was a severe microbial clogging risk from Tank, Furthest Outlet, Subirrigation, and Catchment Basin, with a biological contamination index of $10 / 10$ (Bucks et al., 1979). Biofilms are microbial multicellular structures, often consisting of bacteria, fungi, and algae and extracellular polymers that are produced and excreted by them used to establish on any wet surface including pumps and pipe materials (Kerr et al., 1999; Rogers et al., 2003), plants, fruit, and vegetables (Carmichael et al., 1999). High levels of microbial growth indicate limited water treatment efficacy and the potential to harbor plant pathogens in biofilm.

The Source had low COD and chlorine demand compared with other Sample Types, which did not meet COD guidelines (Table 2). Sample Type and Location significantly affected COD, and chlorine demand was 
Table 4. ANOVA table for effect of sanitation treatments on the $\mathrm{cfu} / \mathrm{mL}$ of aerobic bacteria and yeasts and molds. Samples were collected immediately before (Pretreatment) and immediately after (Posttreatment) each sanitation treatment. The reported density of aerobic bacteria and yeast and mold are least-square mean $\mathrm{cfu} / \mathrm{mL}$ for each Location followed by significance between pretreatment and posttreatment.

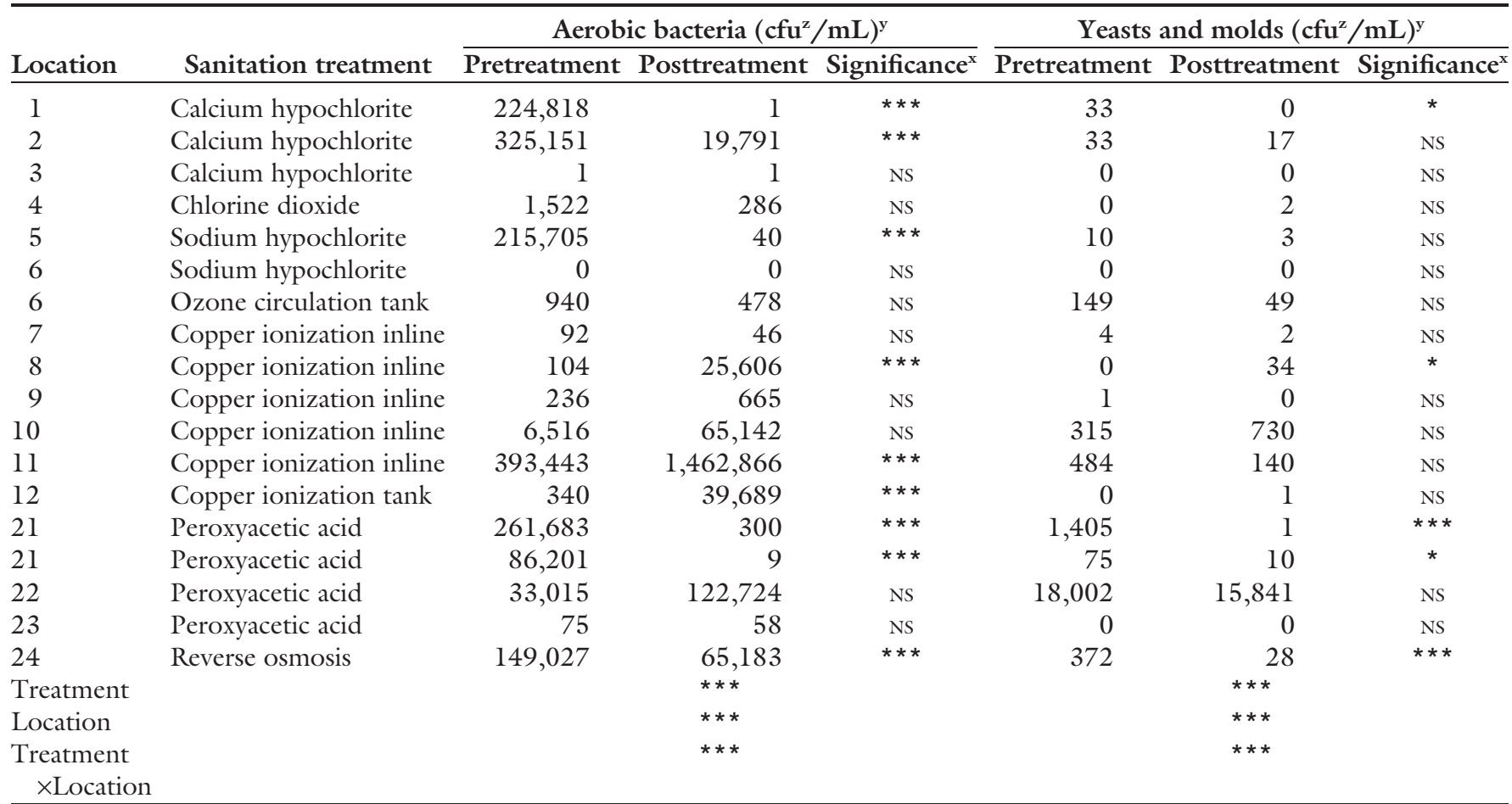

${ }^{2}$ Colony forming units (cfu)

${ }^{\mathrm{y}} \mathrm{l} \mathrm{cfu} / \mathrm{mL}=29.5735 \mathrm{cfu} / \mathrm{fl} \mathrm{oz}$.

${ }^{\mathrm{x}}$ Statistical significance indicated by NS, * ${ }^{* *},{ }^{* * *}$ are either not significant or significant at $P \leq 0.05,0.01$, or 0.001 , respectively.

affected only by Sample Type. Sanitizing agent demand can be quantified directly by measuring the difference between applied and residual active ingredient concentration when a sanitizer is injected into a water sample or indirectly by the COD. The COD represents the amount of oxygen required to completely oxidize contaminants in water and is therefore correlated with the required sanitizing agent concentration (Tanwar et al., 2008). Biodegradable organic matter in reused irrigation water and industrial effluent is monitored for compliance with COD to ensure the sanitizing agent demand is not too high (USEPA, 2004). The COD was highest from Catchment Basin samples, although Catchment Basins had a low chlorine demand compared with most other Sample Types. The low chlorine demand probably occurred in Catchment Basin samples compared with Subirrigation, Tanks, and Furthest Outlet samples because the latter three Sample Types would have contained nitrogen from water-soluble fertilizer. Published guidelines for chlorine demand suggest a minimum free chlorine residual of $1 \mathrm{mg} \cdot \mathrm{L}^{-1}$ after a 30 -min contact time (USEPA, 1999). However, this free chlorine level is unlikely to occur when reduced forms of nitrogen such as ammonium fertilizer are present, resulting in complexed chlorine. Chlorine demand of $8.2 \mathrm{mg} \cdot \mathrm{L}^{-1}$ for Subirrigation water, for example, can be interpreted as a requirement for $10.2 \mathrm{mg} \cdot \mathrm{L}^{-1}$ of applied chlorine to provide $2 \mathrm{mg} \cdot \mathrm{L}^{-1}$ of residual free chlorine.

Changes in microbial water quality from Source to Furthest Outlet (Table 3 ) indicated a general trend of declining water quality as water was distributed through irrigation lines. For both aerobic bacteria and yeast and mold counts, there were significant main or interaction effects for Location, Sample Type, and "Recycled" (a yes/no variable corresponding to whether water was captured and reused between the Source and Furthest Outlet). In one case (Location \#21), there was a significant reduction in aerobic bacteria counts from Source to Furthest Outlet (Table 3), where the Source was from a shallow well followed by treatment with peroxyacetic acid (Table 1). Significant increases in aerobic bacteria between Source and Furthest Outlet occurred in 13 Locations, despite chemical treatment in nine of these cases (Table 3 ). In general, there were higher microbial counts in recycled irrigation. However, there were exceptions such as the high counts in Locations 21, 7, and 8 despite no recycling.

The change in total microbial counts at sampling points before and after sanitizer injection was used as a bioindicator to monitor the capability of the water treatment system to control microorganisms at each Location. Interpretation of the efficacy of the treatment systems is limited by only $\mathrm{l} \mathrm{d}$ of sampling and limited replication of technologies between Locations. There was a significant interaction between Location and Treatment for aerobic bacteria as well as yeasts and molds (Table 4). Eight Locations exceeded the recommended $10,000 \mathrm{cfu} / \mathrm{mL}$ for aerobic bacteria pretreatment, and in four of those cases the posttreatment level was below $10,000 \mathrm{cfu} / \mathrm{mL}$. Irrespective of pretreatment counts of aerobic bacteria were above $10,000 \mathrm{cfu} / \mathrm{mL}$ at 
the posttreatment sampling point, including one Location with calcium hypochlorite, four with copper ionization, one with peroxyacetic acid, and one with reverse osmosis. The high posttreatment bacteria counts indicated several cases where treatment systems were not providing biological irrigation quality within recommended guidelines.

\section{Conclusions}

Monitoring of the physical, chemical, and microbial water quality can improve the efficacy of treatment with reliable control of pathogens without causing corrosion of pumps and equipment (Chang et al., 1998) and to improve environmental safety factors (USEPA, 1999). The highest water quality occurred in Source water, with the exception of $\mathrm{pH}$ (Table 2). Appropriate treatment for alkalinity and $\mathrm{pH}$ in Source water would include acid injection and possibly reverse osmosis.

Sample Types other than the Source tended to have lower UV transmission, and high organic carbon, aerobic bacteria, and COD, and not all systems were managing microbial load. The greatest potential risk of clogged emitters in irrigation systems resulted from aerobic bacteria levels above $10,000 \mathrm{cfu} / \mathrm{mL}$. Of the eight Locations with pretreatment bacterial counts above $10,000 \mathrm{cfu} / \mathrm{mL}$ (Table 4 ), treatment lowered bacteria counts below $10,000 \mathrm{cfu} / \mathrm{mL}$ in only half the Locations. Improvements to irrigation systems are required to reduce bacteria counts, including increased filtration to remove suspended particles and overall sanitizing demand, followed by more effective chemical treatment.

These results highlight that monitoring of biological, chemical, and physical water quality can be used to improve irrigation system design when implementing a water treatment technology. The density of aerobic bacteria can be counted to indicate the relative efficacy of a treatment technology to control microbes in greenhouse and nursery irrigation, particularly when providing chemical treatments or microemitter irrigation using recycled water. More detailed analysis of pretreatment and posttreatment for each Location should be conducted to determine if the treatment systems were effective or failed in control of aerobic bacteria, yeast, and mold.
This survey was not intended for comparison between treatment technologies because it was conducted at only one point in time. Installation of sampling ports before and after each treatment point should be a standard design feature to improve the ability to monitor irrigation quality. Regular monitoring of sanitizing agent levels and biological water quality may provide assessment of the water quality changes that are likely to occur over time and within a horticultural irrigation system. Before this survey, none of the Locations had measured physical water quality and pretreatment and posttreatment water quality variables such as aerobic bacteria counts, which are important monitoring variables to ensure correct operation of a treatment system. The results of this study provide a reference for irrigation quality and may be used as a guideline to develop and implement monitoring procedures to improve irrigation management.

\section{Literature cited}

Agrios, G. 1997. Plant pathology. 4th ed. Academic Press, San Diego, CA.

American Public Health Association. 1995. Standard methods for the evaluation of water and wastewater. 18th ed. Amer. Public Health Assn., Denver, CO.

Argo, W.R., J.A. Biernbaum, and D.D. Warncke. 1997. Geographical characterization of greenhouse irrigation water. HortTechnology 7:49-55.

Association of Agricultural Chemists. 1999. Official methods of analysis. 16th ed. Assn. Agr. Chemists Intl., Boston, MA.

Bucks, D.A., F.S. Nakayama, and R.G. Gilbert. 1979. Trickle irrigation water quality and preventative maintenance. Agr. Water Mgt. 2:149-162.

Carmichael, I., I.S. Harper, M.J. Coventry, P.W.J. Taylor, J. Wan, and M.W. Hickey. 1999. Bacterial colonization and biofilm development on minimally processed vegetables. J. Appl. Microbiol. 85(suppl.):4551 .

Chang, E.E., P.C. Chiang, and T.F. Lin. 1998. Development of surrogate organic contamination variables for source water quality standards in Taiwan. Chemosphere 37:593-606.

Copes, W.E., G.A. Chastaganer, and R.L. Hummel. 2004. Activity of chlorine dioxide in a solution of ions and $\mathrm{pH}$ against Thielaviopsis basicola and Fusarium oxysporum. Plant Dis. 88:188-194.
Feben, D. and M.J. Taras. 1955. Chlorine demand constants. J. Amer. Water Works Assn. 43:922-927.

Gauthier, V., C. Rosin, L. Mathieu, J.M. Portal, J.C. Block, P. Chaix, and D. Catel. 1999. Organic matter as loose deposits in a drinking water distribution system. Water Res. 33:1014-1026.

Gilbert, R.G., F.S. Nakayama, D.A. Bucks, O.F. French, and K.C. Adamson. 1980. Trickle irrigation emitter clogging and other flow problems. Agr. Water Mgt. 3:159-178.

Heibling, D.E. and J.M. VanBriessen. 2008. Continuous monitoring of free chlorine concentrations in response to controlled microbial intrusions in a laboratory scale distribution system. Water Res. 42:3162-3172.

Hong, C.X. and G.W. Moorman. 2005. Plant pathogens in irrigation water: Challenges and opportunities. Crit. Rev. Plant Sci. 24:189-208.

Kerr, C.J., K.S. Osborn, G.D. Robinson, and P.S. Handley. 1999. The relationship between pipe material and biofilm formation in a laboratory model system. J. Appl. Microbiol. 85(suppl.):29-38.

Maier, R.M., I.L. Pepper, and C.P. Gerba. 2009. Environmental microbiology. 2nd ed. Academic Press, Boston, MA.

Newman, S.E. 2004. Disinfecting irrigation water for disease management. 20th Annu. Conf. Pest Mgt. Ornamentals, SanJose, CA, 20-22 Feb. 2004. Soc. Amer. Florists. p. 1-10.

Obreza, T., M. Clark, B. Boman, T. Borisova, M. Cohen, M. Dukes, T. Frazer, E. Hanlon, K. Havens, C. Martinez, K. Migliaccio, S. Shukla, and A. Wright. 2010. A guide to environmental protection agencies numeric nutrient water quality criteria for Florida. Univ. Florida. Inst. Food Agr. Sci. Res. Bul. SL-316.

Pettygrove, G.S. and T. Asano. 1985. Irrigation with reclaimed municipal wastewater a guidance manual. Lewis, Chelsea, MI.

Pirovanni, M., A. Piagentini, D. Guemes, and S. Arkwright. 2004. Reduction of chlorine concentration and microbial load during washing disinfection of shredded lettuce. Int. J. Food Sci. Technol. 39: 341-347.

Ravina, I., E. Paz, Z. Sofer, A. Marcu, A. Schischa, G. Sagi, Z. Yechialy, and Y. Lev. 1997. Control of clogging in drip irrigation with stored treated municipal sewage effluent. Agr. Water Mgt. 33:127-137.

Rogers, D.H., F.R. Lamm, and M. Alam. 2003. Subsurface drip irrigation systems water quality assessment guidelines. Irrigation 


\section{Research Reports}

management series, Kansas State Univ. Agr. Expt Sta. Coop Ext. Serv. Res. Bul. MF-2575.

Runia, W.T. 1994. Disinfection of recirculation water from closed cultivation systems with ozone. Acta Hort. 361:388-396.

Sutton, J.C., C.R. Sopher, T.N. OwenGoing, W. Liu, B. Grodzinski, J.C. Hall, and R.L. Benchimol. 2006. Etiology and epidemiology of pythium root rot in hydroponic crops: Current knowledge and perspectives. Summa Phytopathol. 32:307-321.
Tanwar, P., N. Tapas, U. Pallavi, and P. Manekar. 2008. Correlating on-line monitoring variables, $\mathrm{pH}$, dissolved oxygen and oxidative reduction potential with nutrient removal in an intermittent cyclic process bioreactor system. Bioresour. Technol. 99:7630-7635.

U.S. Environmental Protection Agency. 1999. Alternative disinfectants and oxidants guidance manual. U.S. Environ. Protection Agency, Municipal Support Div., Office Wastewater Mgt., Office Water, Washington, DC.
U.S. Environmental Protection Agency. 2004. Guidelines for water reuse. Rpt. 625/R-04/108:167. U.S. Environ. Protection Agency, Municipal Support Div., Office Wastewater Mgt. Office Water, Washington, DC.

van Os, E.A. 2009. Comparison of some chemical and non-chemical treatments to disinfect a recirculating nutrient solution. Acta Hort. 843:229-234.

Whipker, B.E., J.M. Dole, T.J. Gavins, and J.L. Gibson. 2003. Water quality, p. 9-18. In: D. Hamrick (eds.). Ball redbook crop production. 17th ed. Ball, Batavia, IL. 